\title{
Rotation of topological defects by trapped micro-rods in the nematic phase of a liquid crystal
}

DOI:

10.1016/j.molliq.2017.12.063

10.1016/j.molliq.2017.12.063

\section{Document Version}

Accepted author manuscript

Link to publication record in Manchester Research Explorer

\section{Citation for published version (APA):}

Oh, J., \& Dierking, I. (2018). Rotation of topological defects by trapped micro-rods in the nematic phase of a liquid crystal. Journal of Molecular Liquids. https://doi.org/10.1016/j.molliq.2017.12.063,

https://doi.org/10.1016/j.molliq.2017.12.063

\section{Published in:}

Journal of Molecular Liquids

\section{Citing this paper}

Please note that where the full-text provided on Manchester Research Explorer is the Author Accepted Manuscript or Proof version this may differ from the final Published version. If citing, it is advised that you check and use the publisher's definitive version.

\section{General rights}

Copyright and moral rights for the publications made accessible in the Research Explorer are retained by the authors and/or other copyright owners and it is a condition of accessing publications that users recognise and abide by the legal requirements associated with these rights.

\section{Takedown policy}

If you believe that this document breaches copyright please refer to the University of Manchester's Takedown Procedures [http://man.ac.uk/04Y6Bo] or contact uml.scholarlycommunications@manchester.ac.uk providing relevant details, so we can investigate your claim.

\section{OPEN ACCESS}




\section{Rotation of topological defects by trapped micro-rods in the nematic phase of a liquid crystal}

\section{Jiyoung Oh}

\section{Ingo Dierking}

ingo.dierking@manchester.ac.uk

School of Physics and Astronomy, University of Manchester, Oxford Road, Manchester M13 9PL, United Kingdom

${ }^{*}$ Corresponding author.

\section{Abstract}

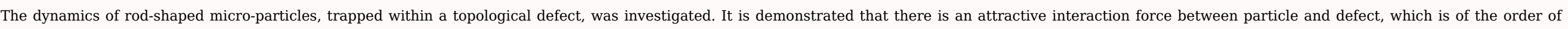

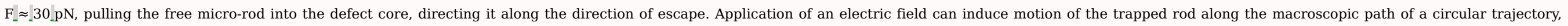

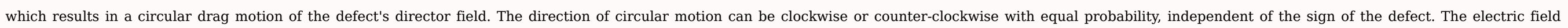
dependence of trajectory diameter and angular velocity are investigated, and it is found that these lead to a velocity, which is largely independent of electric field and particle-defect rotation direction.

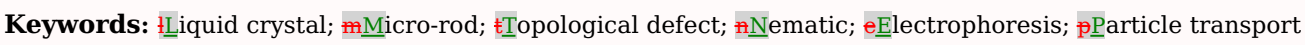

\subsection{Introduction}

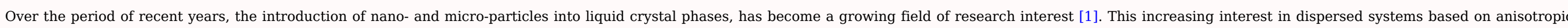

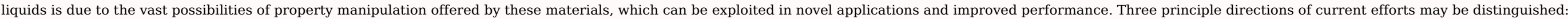

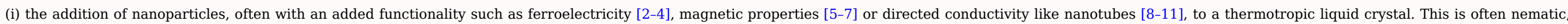
but can be also be ferroelectric by itself [12-14], such as the SmC* phase, or discotic $[15,16]$ or even lyotropic $[17,18]$.

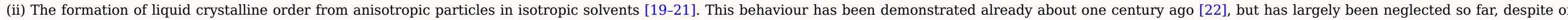

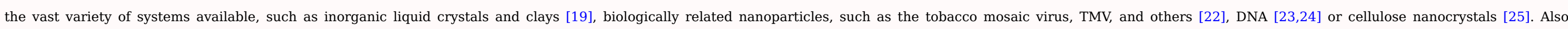
nanotubes and graphene oxide [26-30], as well as other micro-rod and nanowire materials can exhibit lyotropic liquid crystalline ordering.

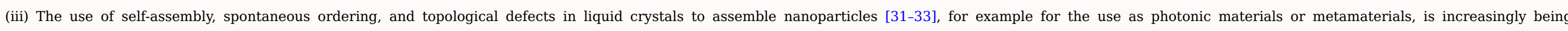
investigated.

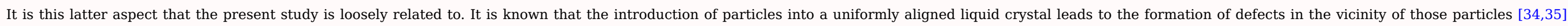

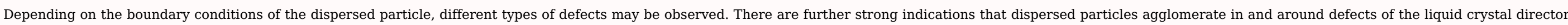

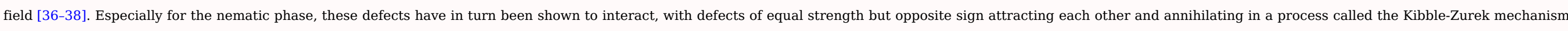

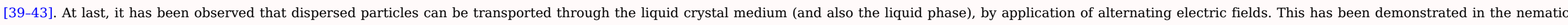

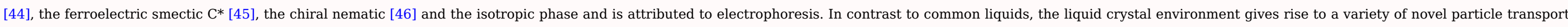

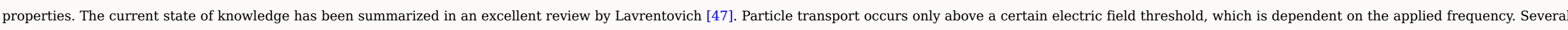

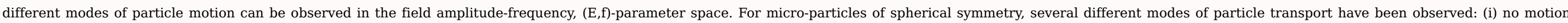

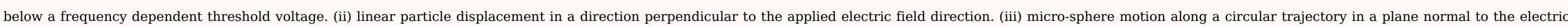

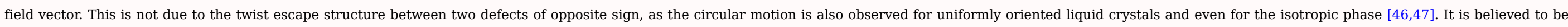




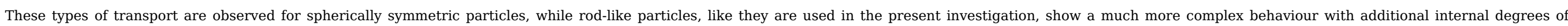

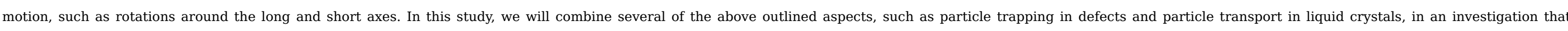
describes particle mediated defect transport.

\subsection{Experimental}

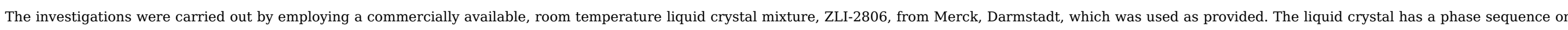

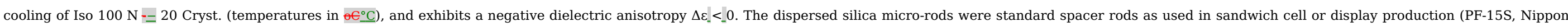

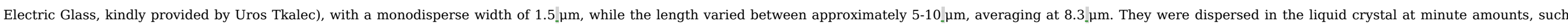

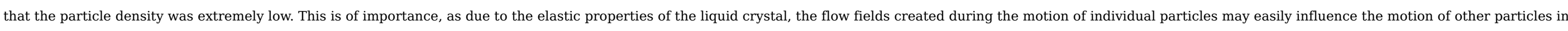

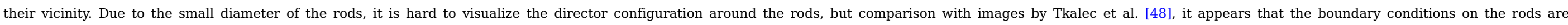
homeotropic and leading to a dipolar defect configuration.

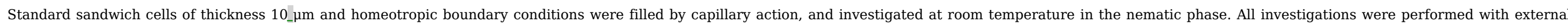

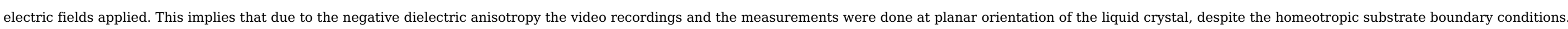
This procedure was necessary in order to induce the umbilic defects in the nematic director field.

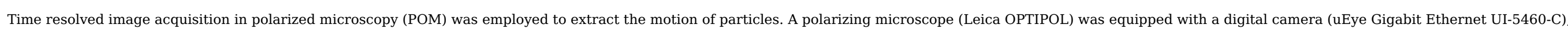

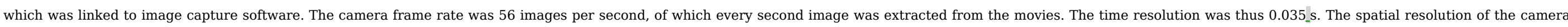

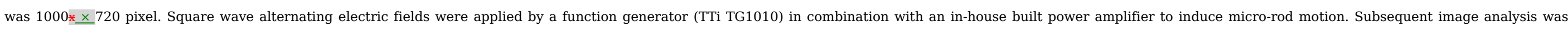
carried out with software ImageJ, developed at the National Institutes of Health, Maryland, USA.

\subsection{Experimental Rresults and Đdiscussion}

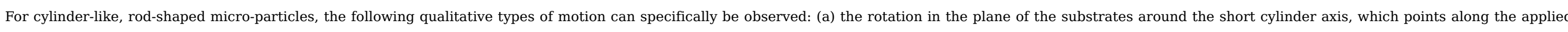

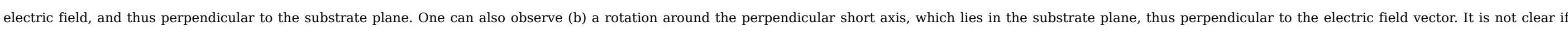

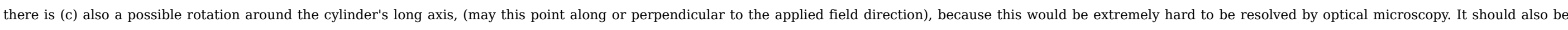

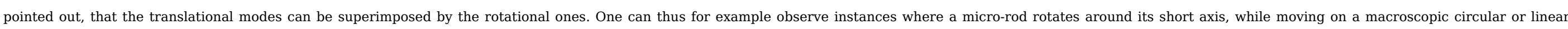
trajectory.

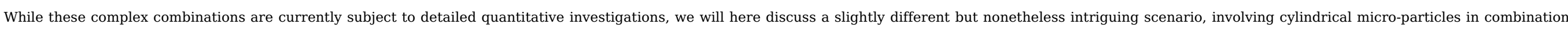

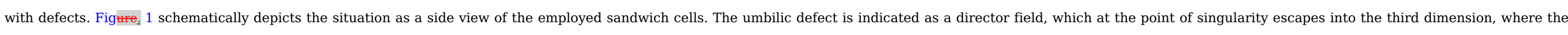

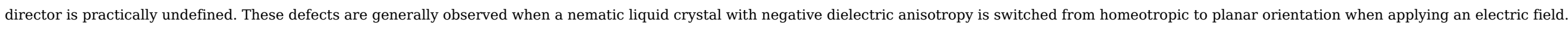


A

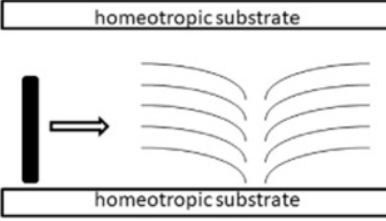

homeotropic substrate

B
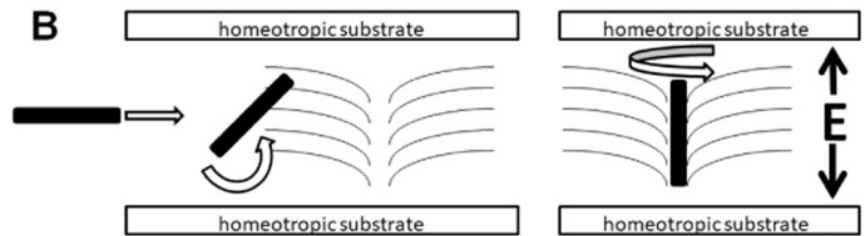

sandwich cell side view

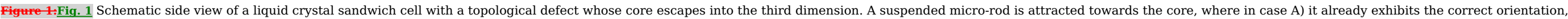

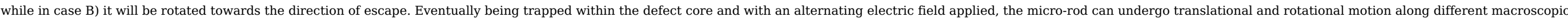
trajectories.

alt-text: Fig. 1

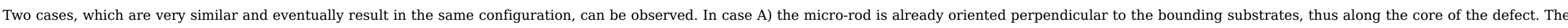

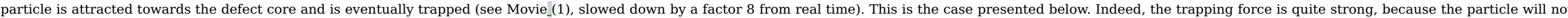

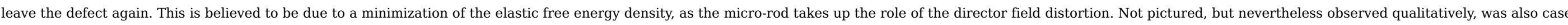

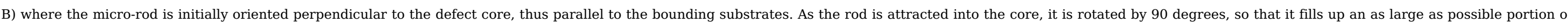

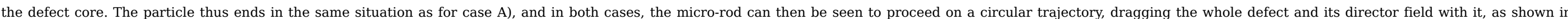
Movie_(2)

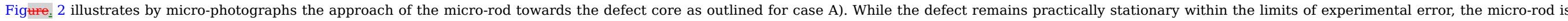

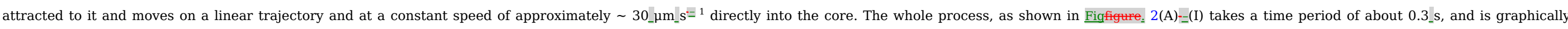

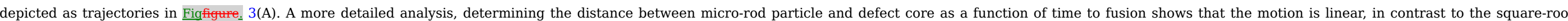

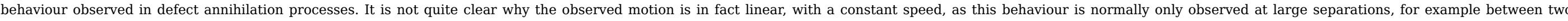

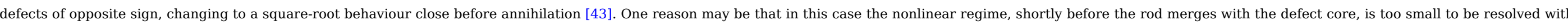

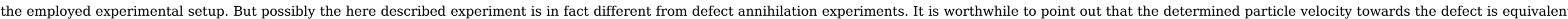

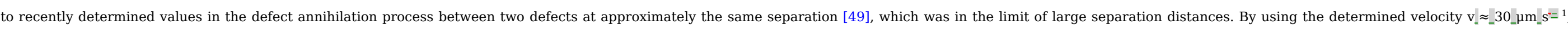

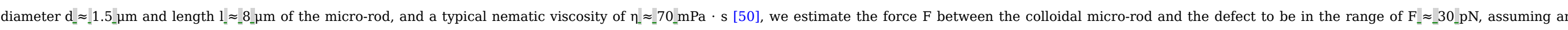

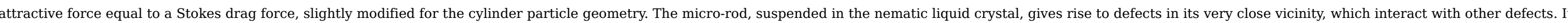

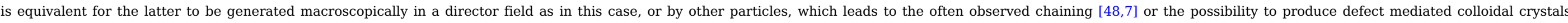
[31,32] 


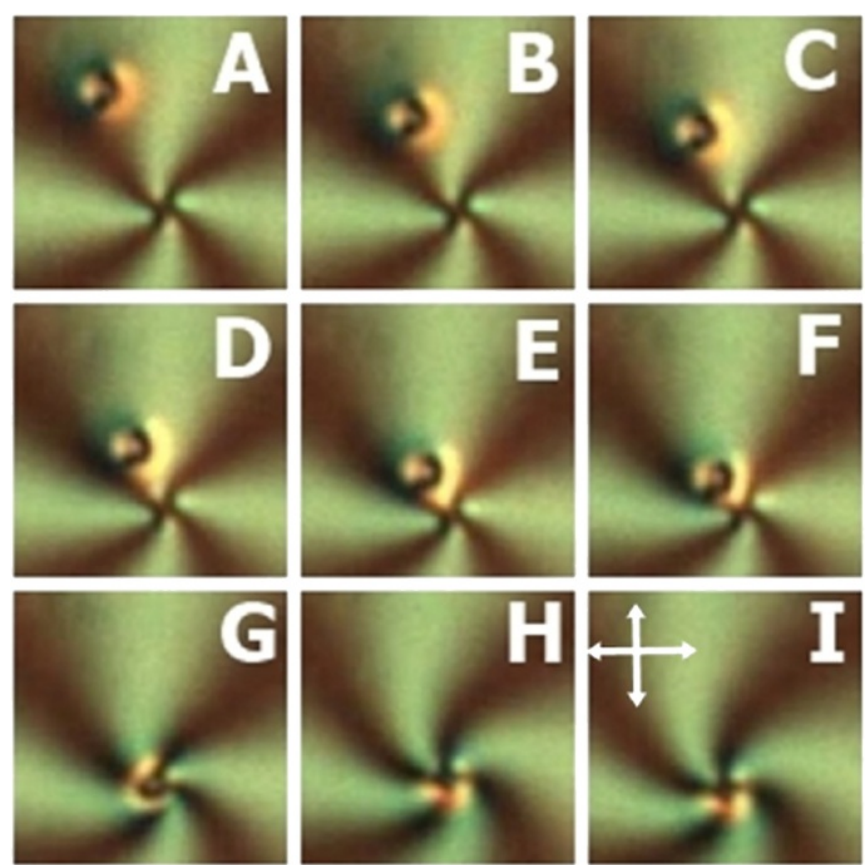

Figure 2:Fig. 2

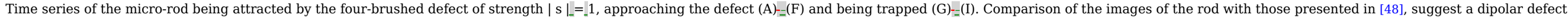

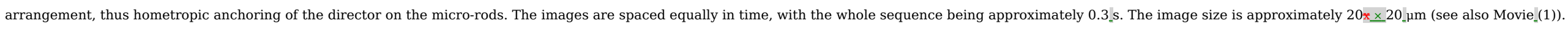
alt-text: Fig. 2
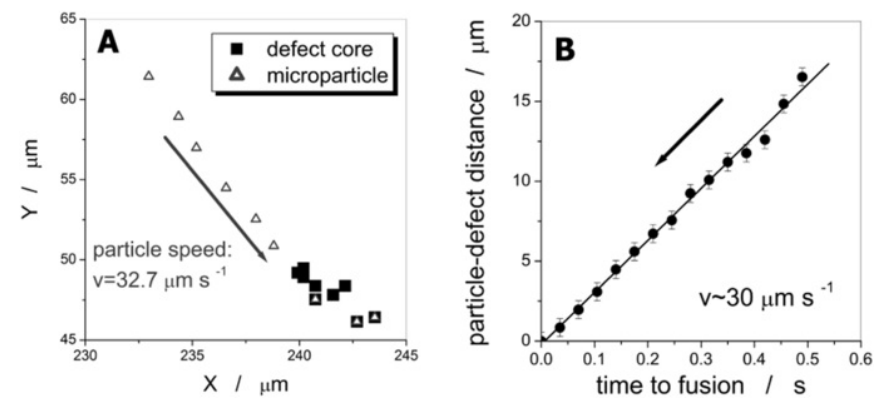

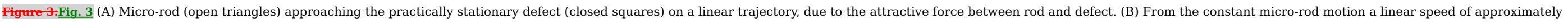
$\mathrm{v} \_\approx 30 \_\mu \mathrm{m}_{-} \mathrm{s}=1$ can be determined.

alt-text: Fig. 3

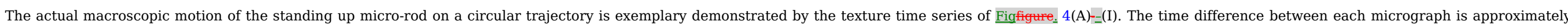
$\sim 0.35$ _s. Movie_(2) provides the corresponding dynamic, visual impression. The movie is slowed down by a factor 8 in comparison to real time.

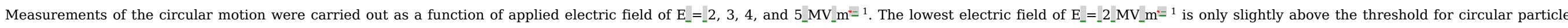

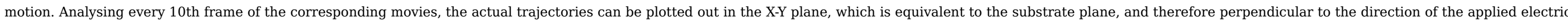




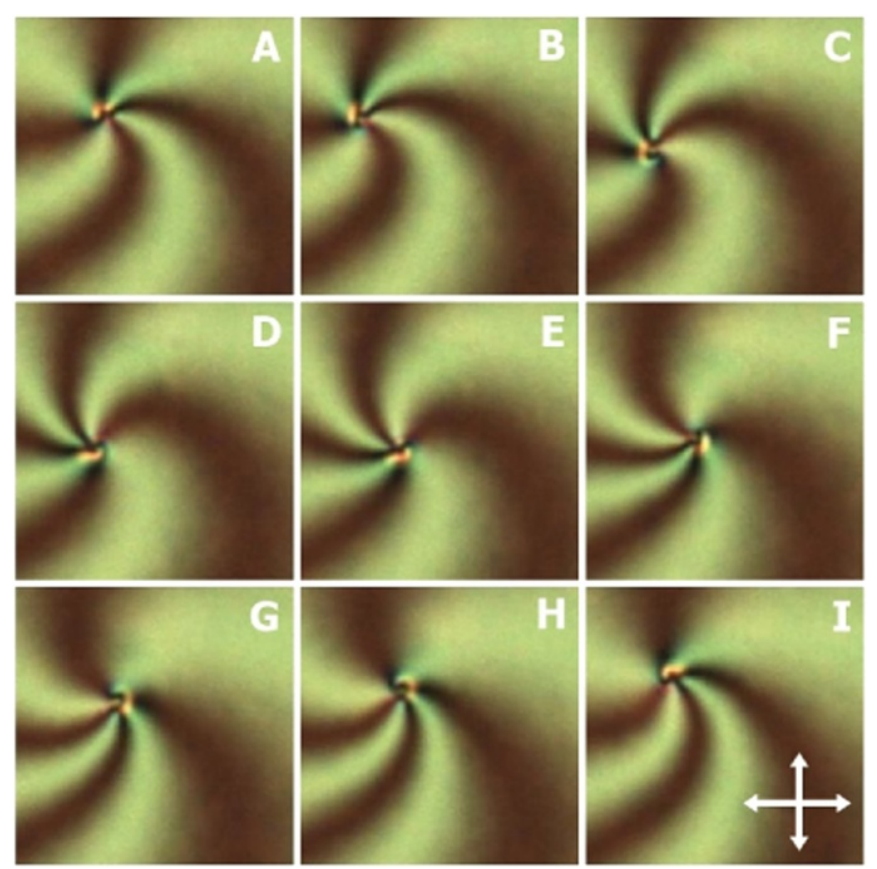

Figure 4:Fiq. 4

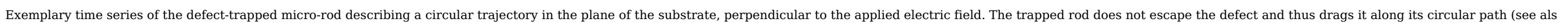

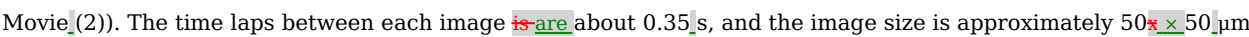
alt-text: Fig. 4 

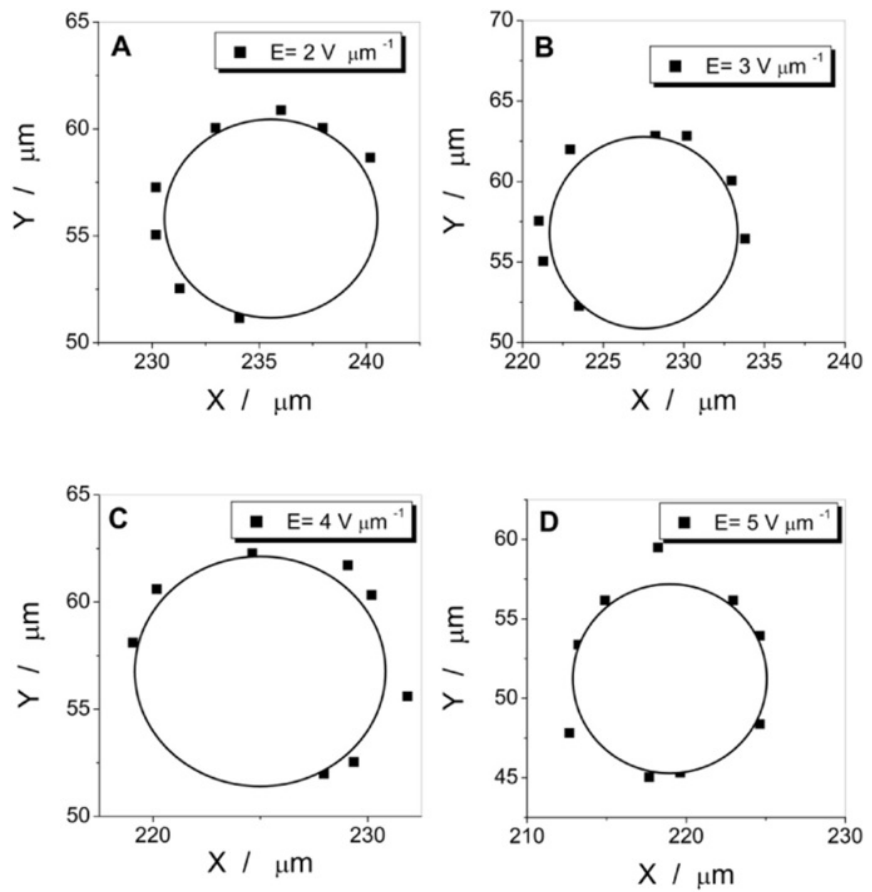

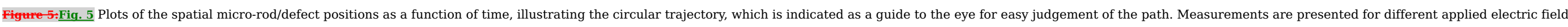

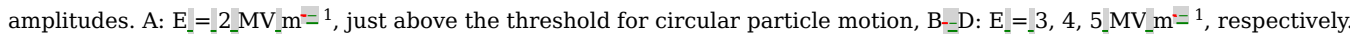

alt-text: Fig. 5

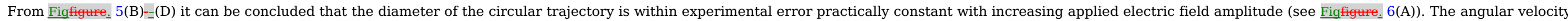

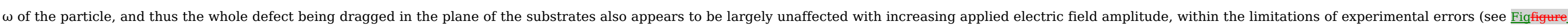

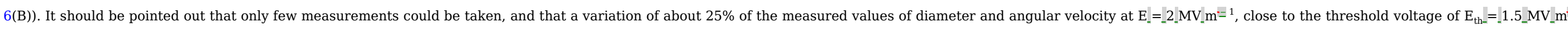

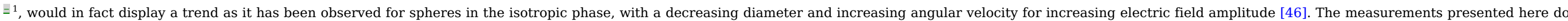
carry a relatively large error, which is most likely due to the mutual influence of the flow fields created by defects and other particles in the vicinity.
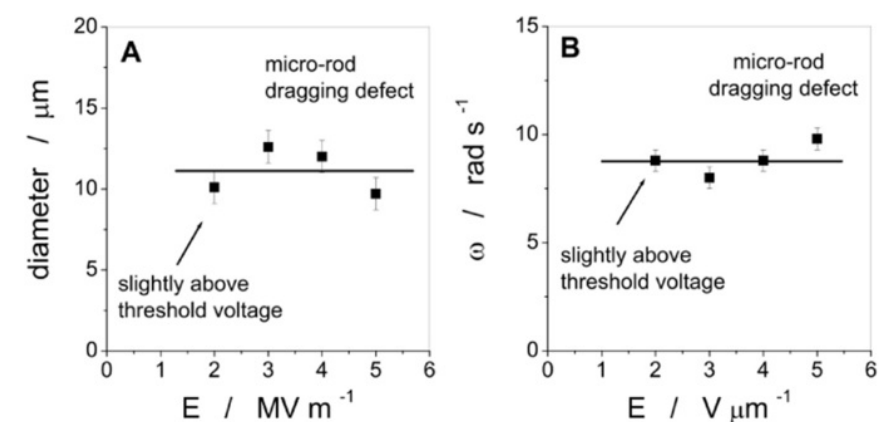

Figure 6:Fig. 6 Electric field amplitude dependence of A: the diameter and B: the angular velocity of the micro-rod/defect system moving on the circular trajectory. 


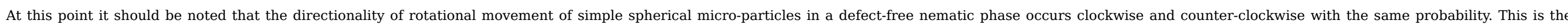

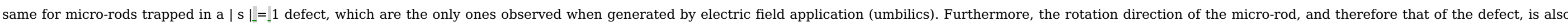
not related to the sign of the defect strength. This is demonstrated by Movie_(3), which is slowed down by a factor 4 in comparison to real time, and as a time series of textures in Figfigure. 7 .

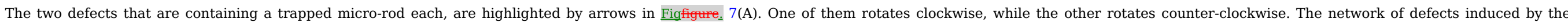

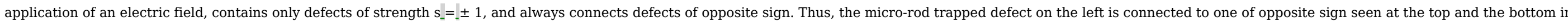

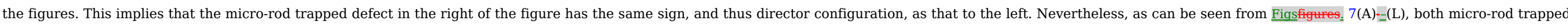
defects rotate in opposite directions.
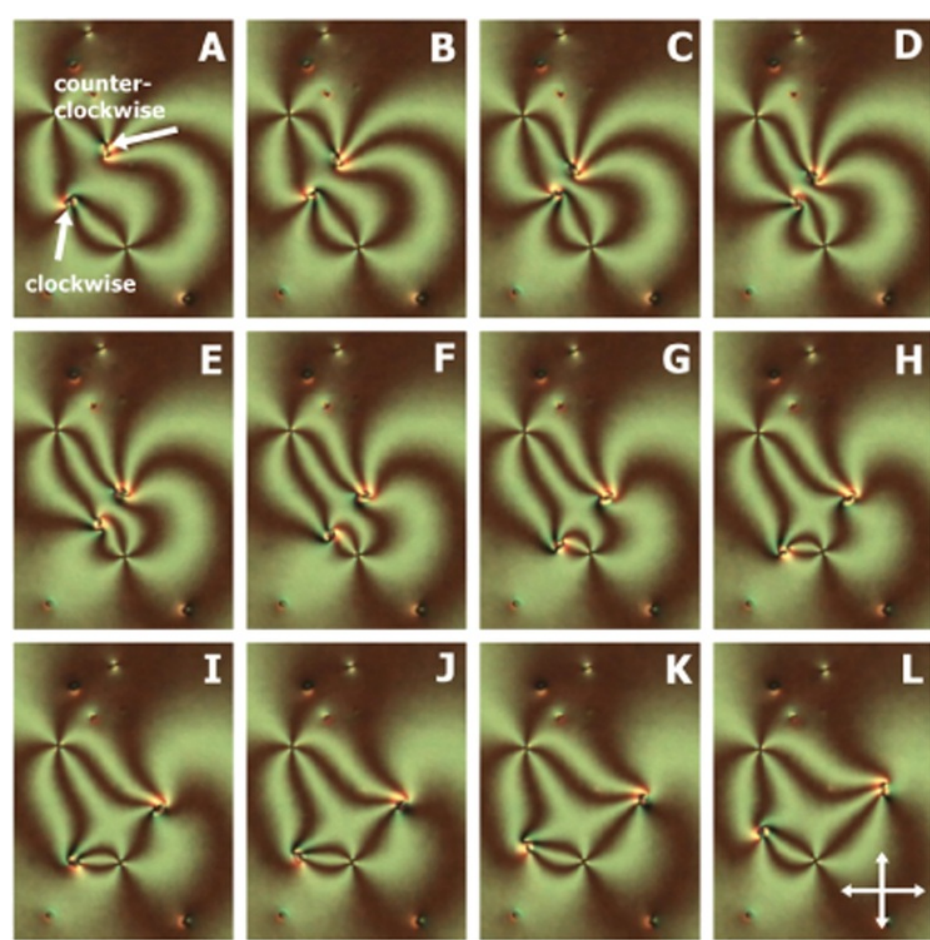

Figure 7.Fiq. 7

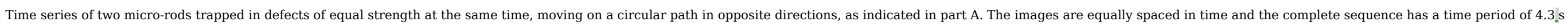
(see also Movie (3)). The image size is approximately $\left.40 * \underline{*} \times 50 \mu \mathrm{m}, \mathrm{E}_{-}=\mid 2 \_\mathrm{MV}\right] \mathrm{m}=1$.

alt-text: Fig. 7

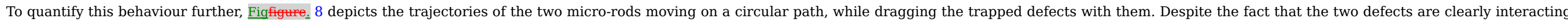

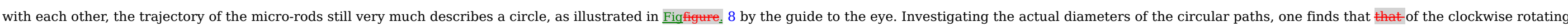

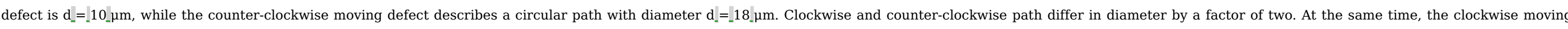

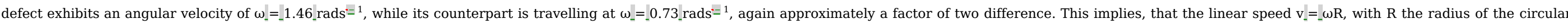

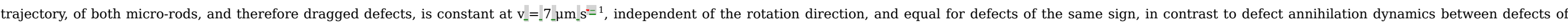
opposite sign translate at different speeds [43] 


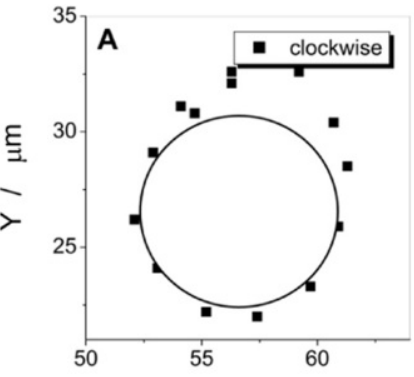

$\mathrm{X} / \mu \mathrm{m}$

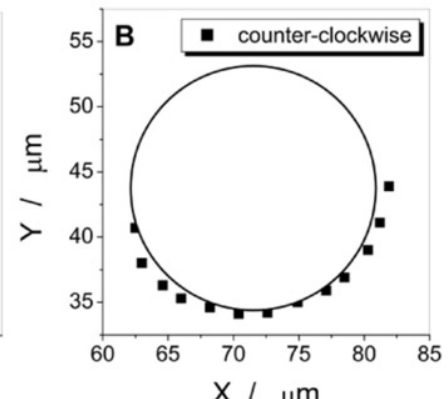

$\mathrm{X} / \mu \mathrm{m}$

Figure 8:Fiq. 8

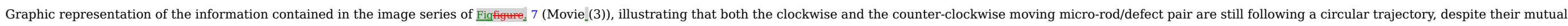

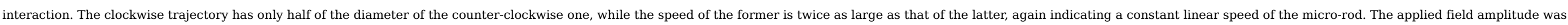
$\mathrm{E}_{-}=-2\left[\mathrm{MV} \_\mathrm{m}=1\right.$. Circles are a guide to the eye to judge the particle trajectory.

\section{4.}

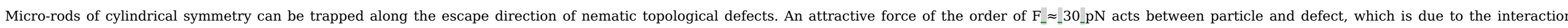

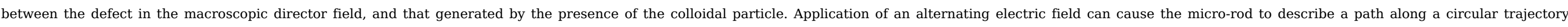

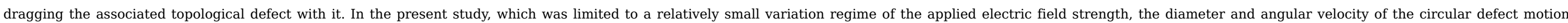

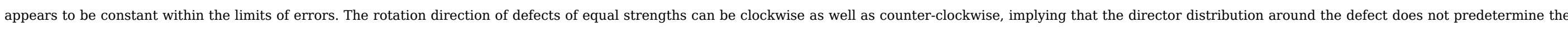
rotation direction.

Supplementary data to this article can be found online at https://doi.org/10.1016/j.molliq.2017.12.063.

\section{References}

[1] J.P.F. Lagerwall and G. Scalia, (Eds.), Liquid Crystals with Nano and Microparticles, 2017, World Scientific; Singapore.

[2] Y. Reznikov, O. Buchnev, O. Tereshchenko, V. Reshetnyak, A. Glushchenko and J. West, Appl. Phys. Lett. 82, 2003, 1917.

[3] F.H. Li, J. West, A. Glushchenko, C. Il Cheon and Y. Reznikov, J. Soc. Inf. Disp. 14, 2006, 523.

[4] S. Al-Zangana, M. Turner and I. Dierking, J. Appl. Phys. 121, 2017, 085105.

[5] N. Podoliak, O. Buchnev, O. Buluy, G. D'Alessandro, M. Kaczmarek, Y. Reznikov and T.J. Sluckin, Soft Matter 7, 2011, 4742.

[6] A. Mertelj, D. Lisjak, M. Drofenik and M. Copic, Nature 504, 2013, 237

[7] I. Dierking, M. Heberle, M.A. Osipov and F. Giesselmann, Soft Matter 13, 2017, 4636.

[8] I. Dierking, G. Scalia, P. Morales and D. LeClere, Adv. Mater. 16, 2004, 865.

[9] I. Dierking, G. Scalia and P. Morales, J. Appl. Phys. 97, 2005, 044309.

[10] J.P.F. Lagerwall and G. Scalia, J. Mater. Chem. 18, 2008, 2890.

[11] S.P. Yadav and S. Singh, Prog. Mater. Sci. 80, 2016, 38. 
[12] F.V. Podgornov, A.M. Suvorova, A.L. Lapanik and W. Haase, Chem. Phys. Lett. 479, 2009, 206.

[13] J. Prakash, A. Choudhary, D.S. Metha and A.M. Biradar, Phys. Rev. E 80, 2009, 012701.

[14] M. Yakemseva, I. Dierking, N. Kapernaum, N. Usoltseva and F. Giesselmann, Eur. Phys. J. E 37, 2014, https://doi.org/10.1140/epje/i2014-14007-4.

[15] S. Kumar and H.K. Bisoyi, Angew. Chem. Int. Ed. 46, 2007, 1501.

[16] H.K. Bisoyi and S. Kumar, J. Mater. Chem. 18, 2008, 3032.

[17] J. Lagerwall, G. Scalia, M. Haluska, U. Dettlaf-Weglikowska, S. Roth and F. Giesselmann, Adv. Mater. 19, 2007, 359.

[18] W. Jiang, B. Yu, W. Liu and J. Hao, Langmuir 23, 2007, 8549 .

[19] A.S. Sonin, J. Mater. Chem. 8, 1998, 2557.

[20] J.C.P. Gabriel and P. Davidson, Colloid Chemistry 1 in Topics in Current Chemistry, 226, 2003, 119.

[21] I. Dierking and S. Al-Zangana, Nanomaterials, 2017, (submitted).

[22] H. Diesselhorst and H. Freundlich, Phys. Z. 16, 1915, 419.

[23] T.E. Strzelecka, M.W. Davidson and R.L. Rill, Nature 331, 1988, 457.

[24] F. Livolant and A. Leforestier, Prog. Polym. Sci. 21, 1996, 1115.

[25] X.M. Dong, T. Kimura, J.F. Revel and D.G. Gray, Langmuir 12, 1996, 2076.

[26] W. Song, I.A. Kinloch and A.H. Windle, Science 302, 2003, 1363.

[27] S. Badaire, C. Zakri, M. Maugey, A. Derre, J.N. Barisci, G. Wallace and O. Poulin, Adv. Mater. 13, 2005, 1673.

[28] J.E. Kim, T.H. Han, S.H. Lee, J.Y. Kim, C.W. Ahn, J.M. Yun and S.O. Kim, Angew. Chem. Int. Ed. 50, 2011, 3043.

[29] Z. Xu and C. Gao, Nature Comm. 2, 2011, 571, (DOI: 10.1038.ncomm1583).

[30] S. Al-Zangana, M. Iliut, M. Turner, A. Vijayaraghavan and I. Dierking, 2D, Dent. Mater. 2017, (in press).

[31] I. Musevic, M. Skarabot, U. Tkalec, M. Ravnik and S. Zumer, Science 313, 2006, 954.

[32] I. Musevic and M. Skarabot, Soft Matter 4, 2008, 195.

[33] I. Musevic, Liq. Cryst. Rev. 4, 2016, 1.

[34] P. Poulin, H. Stark, T.C. Lubensky and D.A. Weitz, Science 275, 1997, 1770.

[35] H. Stark, Eur. J. Phys. B 10, 1999, 311.

[36] I. Dierking, W. Blenkhorn, E. Credland, W. Drake, R. Kociuruba, B. Kayser and T. Michael, Soft Matter 8, 2012, 4355.

[37] A.C. Pawsey, J.S. Lintuvuori, T.A. Wood, J.H.J. Thijssen, A. Marenduzzo and P.S. Clegg, Soft Matter 8, 2012, 8422

[38] A.C. Pawsey and S. Clegg, Soft Matter 11, 2015, 3304.

[39] I. Chuang, B. Yurke, R. Durrer and N. Turok, Science 251, 1991, 1336.

[40] A. Pargellis, N. Toruk and B. Yurke, Phys. Rev. Lett. 67, 1991, 1570. 
[41] I. Chuang, B. Yurke, A.N. Pargellis and N. Toruk, Phys. Rev. E 47, 1993, 3343.

[42] I. Dierking, O. Marshall, J. Wright and N. Bulleid, Phys. Rev. E 71, 2005, 061709.

[43] I. Dierking, M. Ravnik, E. Lark, J. Healey, G.P. Alexander and J.M. Yeomans, Phys. Rev. E 85, 2012, 021703.

[44] I. Dierking, G. Biddulph and K. Matthews, Phys. Rev. E 73, 2006, 011702.

[45] I. Dierking, P. Cass, K. Syres, R. Cresswell and S. Morton, Phys. Rev. E 76, 2007, 021707.

[46] J. Oh, H.F. Gleeson and I. Dierking, Phys. Rev. E 95, 2017, 022703.

[47] O.D. Lavrentovich, Soft Matter 10, 2014, 1264.

[48] U. Tkalec, M. Skarabot and I. Musevic, Soft Matter 4, 2008, 2402.

[49] M. Nikkhou, M. Skarabot and I. Musevic, Phys. Rev. E 93, 2016, 062703.

[50] A.G. Chmielewski, Mol. Cryst. Liq. Cryst. 132, 1986, 339.

\section{$\nabla$ E-Extra}

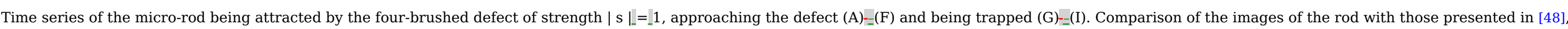

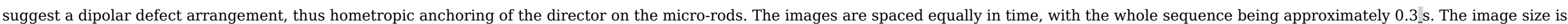
approximately $20 * \underline{*} 20 \mu \mu \mathrm{m}$ (see also Movie_(1)).

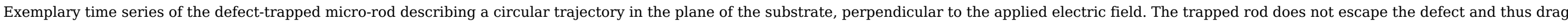

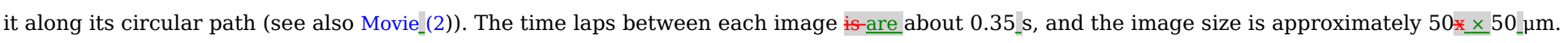

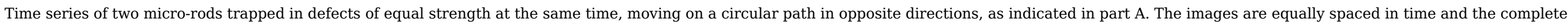
sequence has a time period of $4.3 \mathrm{~s}$ (see also Movie_(3)). The image size is approximately $40 * \underline{*} \times 50 \_\mu \mathrm{m}, \mathrm{E}_{-}={ }_{2} \_\mathrm{MV} \_\mathrm{m}=1$.

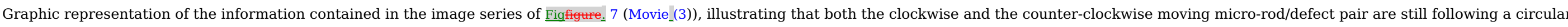

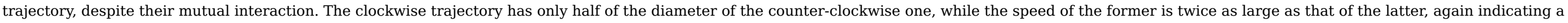
constant linear speed of the micro-rod. The applied field amplitude was $\mathrm{E}_{-}={ }_{-} 2 \mathrm{MV}\left[\mathrm{m}={ }^{1}\right.$. Circles are a guide to the eye to judge the particle trajectory.

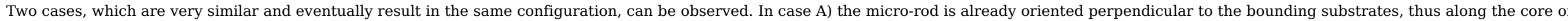

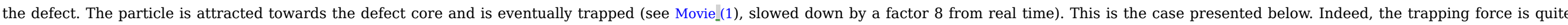

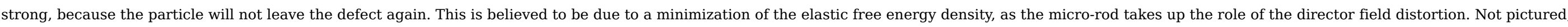

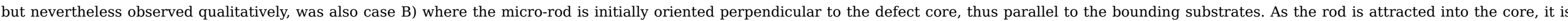

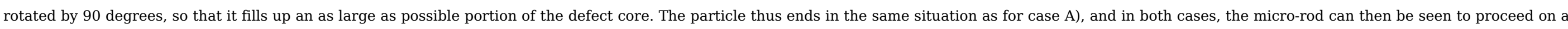
circular trajectory, dragging the whole defect and its director field with it, as shown in Moviel(2).

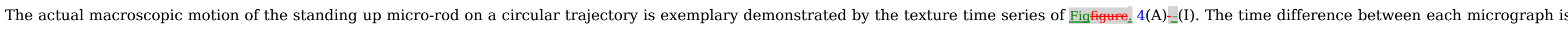
approximately 0.35_s. Movie_(2) provides the corresponding dynamic, visual impression. The movie is slowed down by a factor 8 in comparison to real time.

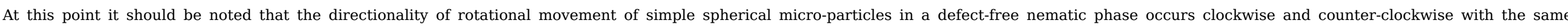

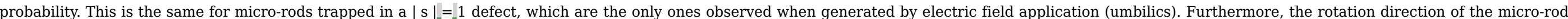

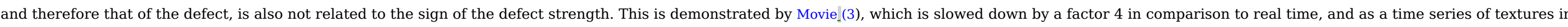


Figfigure. 7.

$\nabla$ E-component

The following are the supplementary data related to this article.

Multimedia Component

Supplementary video 1

alt-text: Supplementary video 1

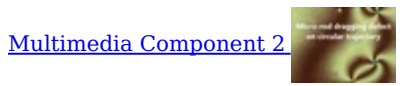

Supplementary video 2

alt-text: Supplementary video 2

Multimedia Component 3 ब बके

Supplementary video 3

alt-text: Supplementary video 3

\section{Highlights}

- Demonstration of defect trapping of micro-rod particles in liquid rystals

- Estimation of attractive force between particle and defect to $\mathrm{F}_{-} \sim{ }_{2}{ }_{-} \mathrm{pN}$

- First demonstration of regular defect dragging on circular trajectory by moving micro-rod

- Demonstration of independence of motion on defect sign

- First detailed study of rod-like particle electrophoresis in liquid crystals

\section{Queries and Answers}

\section{Query:}

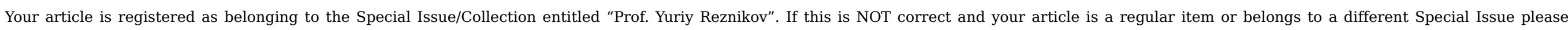
contact santhoshi.bs@elsevier.com immediately prior to returning your corrections.

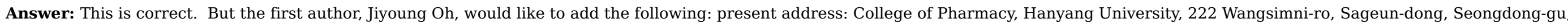
Seoul, South Korea.

\section{Query:}

Please confirm that given names and surnames have been identified correctly and are presented in the desired order, and please carefully verify the spelling of all authors' names. Answer: Yes. 
Query:

The author names have been tagged as given names and surnames (surnames are highlighted in teal color). Please confirm if they have been identified correctly.

Answer: Yes

Query:

Please provide caption for Supplementary video 1.

Answer: Micro-rod attracted by defect

Query:

Please provide caption for Supplementary video 2.

Answer: Circular defect trajectory caused by trapped micro-rod.

Query:

Please provide caption for Supplementary video 3.

Answer: Defect pair rotation.

Query:

Please provide an update for reference "[30]".

Answer: S. Al-Zangana, M. Iliut, M. Turner, A. Vijayaraghavan, I. Dierking, 2D Mater., 4, (2017), 041004 